\title{
Experimental Analysis of Adobe Flash CS6 Based Instructional Media Development In Accounting Subject
}

\author{
Suranto $^{1}$, Annisa Ratnasari ${ }^{2}$ \\ \{ $\underline{\text { sur122@ums.ac.id, annisaratnasari79@gmail.com }\}}$ \\ 1,2,Universitas Muhammadiyah Surakarta, Surakarta, Indonesia
}

\begin{abstract}
The purpose of this study is to compare the achievement of students' activeness and learning outcomes in the teaching-learning process using Adobe Flash CS6 interactive media-based multimedia compared to conventional learning in Accounting with the material on journal adjustment for Vocational Middle School students. The research method used was the quasi-experiment method with the pretest-posttest control group design. The population of this research is first year vocational middle school students. Data sampling was conducted using the purposive sampling technique for the experiment class and the controller class. The data collecting technique used was observation, test, and documentation. The analysis technique used to test the result of this research was the independent sample t-test. The result of this research showed that there is a difference in the activeness of the students' learning in the learning process using the Adobe Flash CS6 interactive media-based multimedia compared to conventional learning. The result of the $\mathrm{t}$-test with the significance level of $5 \%$ showed a significant difference of $12,889 \geq 1,994$ between the experiment class and the controller class. The average rate of students' activeness from the result of the observation instrument was 51.42 for the experiment class and a lower result for the controlled class with 40.30. Furthermore, it is also proven that there is a difference in the learning outcome of learning using the Adobe Flash CS6 interactive media-based multimedia compared to conventional learning. From the result of the t-test, there was a significant difference of $14,254 \geq 1,994$. The average rate of students' learning outcome of the experiment class was 89.72 , whereas the controlled room was 71.25. The gain score of the experiment class was within the high category while the controlled class was within the moderate category.
\end{abstract}

Keywords: instructional media, Adobe Flash CS6, students' learning activeness, students' learning outcome.

\section{Introduction}

Teachers as educators are required to be able to deliver the materials optimally and liven up the teaching-learning process. The teaching-learning process is a two-way process that cannot be separated between the teacher and the students. In this process, the educator delivers material that has been appropriated to the goal of the study with the means of educating the students. The best teacher is those who provide education that is understandable, easy, interesting, implements proper class management, and builds a strong relationship with their students [1]. 
The curriculum in Indonesia has undergone many changes. Until this day, the curriculum has always prioritized the role of students within the teaching-learning process to increase their information or knowledge. The purpose of an educator is more of a facilitator, where students can obtain experience with the guidance of the teacher [2]. Essentially, the active role of students in the modern world of education is a significant necessity [3].

The learning process is expected to raise and increase the active role and participation of students in developing their learning capacity, potential, and talent. When they are engaged in learning, students carry out many activities [4]. The activeness of a student in the learning process can stimulate and develop their talents, critical thinking, and problem-solving in everyday situations [5]. They use their brains in learning ideas, solving problems, and implementing what they have learned [6]. Active learning is learning quickly, fun, full of enthusiasm, and engaging personality to learn something well, must listen, see, and answer the questions and discuss with peers[7].

In the learning and teaching process, aside from the students' activeness, the learning outcome and students' learning mastery are also extremely important to be taken into account, because they are one of the goals that need to be achieved. The learning outcome shows the skills, will, knowledge, and grades that can be measured that students must make after completing a task [8].

The learning process is a communication process that takes place within a system. Hence the instructional media occupies a reasonably necessary position as one of the components of the learning system in reaching the intended learning goals [9] [10]. The result of a study conducted by Ogott and Odera [11] found that with the existence of various instructional media, from 38 teachers $65.8 \%$ said that it is extremely helpful, $13.3 \%$ said it is helpful, $10.5 \%$ said it gave ease in understanding the learning material, and the rest stated that it is not helpful.

However, in reality, instructional media has not been optimally used by a majority of teachers in the learning process. The result of the researcher's observation at a Vocational Middle School in the Boyolali District, Central Java, shows that a majority of teachers that dominantly use lecturing method in the learning process. Teachers use conventional methods such as lecturing because of the lack of knowledge of using or developing innovative and creative instructional media that can help the learning process and the learning outcome of the students. This conventional method makes the learning process less exciting and monotonous without much variation. Hence students tend to be bored and become passive during the learning process because the communication seems to be one way. This thus causes the students' learning outcome to decrease. In line with the research conducted by Aksit et al [12] that stated that many factors hinder students to actively learn, such as the lack of instructional media which makes students passive, incompetent educators, lack of time and time pressure during the learning process, teacher's lack of skills. The most dominant obstacle, in this case, leans more towards the instructional media used.

The use of instructional media is an alternative in solving various problems faced by students during the learning process [13]. The technology of interactive multimedia empowers the education process by increasing the interaction between teachers and students [14]. Students satisfaction in learning is an essential part of developing their skills and knowledge to improve the students' learning outcome.

From the discussion that has been elucidated related to the influence of instructional media towards the learning process and the students' learning outcome. The goal of this study is to prove the advantages of instructional media in increasing students' activeness and their learning outcomes by experimenting using the development of instructional media with the Adobe Flash CS6 software in the learning process of Accounting on Vocational Middle school students. The 
Adobe Flash CS6 software is used because of its various features that ease the process of creating an instructional media. Adobe Flash CS6 can load texts, pictures, sound, animation, videos, and films according to the needs of the creator and is equipped with interactive buttons [15]. Classes that use Adobe Flash CS6 based instructional media development will be compared to classes that use conventional teaching methods. The result of the study is expected to provide knowledge on the influence of instructional media in classes, especially in learning Accounting. Therefore, it will contribute ideas related to how the learning process should be conducted.

\section{Method}

This research uses Quasi-experiment. Quasi-experiment research is used to find the influence of a specific treatment in the condition where the researcher cannot fully control and manipulate freely and intensively [16]. This research uses the pretest-postest Control Group Design [17]. There are two variables in this research, which are independent variables (the instructional media) and dependent variables (students' activeness and learning outcome). The population in this research is three classes of first-year students of SMK (Vocational middle school) Negeri 1 Boyolali, Central Java Province, Indonesia. The data sampling technique used was purposive sampling. The determination of the experiment group and the controlled group was through consideration and observation. Thus, class XAK1 was selected as the controlled class and class XAK3 as the experiment class. The data collection technique used in this research was observation sheets, tests, and documentation. The students' activeness was assessed using the observation sheets, whereas the learning outcome was evaluated through the test. Instrument trial test was conducted using the instrument validity test and instrument reliability test. The analysis technique used pre-analysis requirement test, which is the data normality test and homogeneity test. The hypothesis test used the independent sample t-test with the significance level of 5\% and the gain score of the students' learning outcome variable. Data processing was conducted using the assistance of the SPSS program.

\section{Result and Discussion}

Interactive multimedia in this research is through creating an instructional media using the Adobe Flash Professional CS6. Flash is usually used to create animation, commercials, and various components of websites [15]. Adobe Flash Professional CS6 has a .swf extension and can be played in the Flash Player. The advantages of an instructional media using the Adobe Flash Professional CS6 are: flash files are small in size, all types of picture files and audio files can be inserted, animations can be controlled as desired, able to create executable files (*.exe) hence can be played in any PC without having to install anything [18]. The font of the presentation will not change in any PC. The creation of an Adobe Flash Professional CS6 based instructional media was created with an attractive appearance and menus according to the needs of the learning process (see picture 1). 


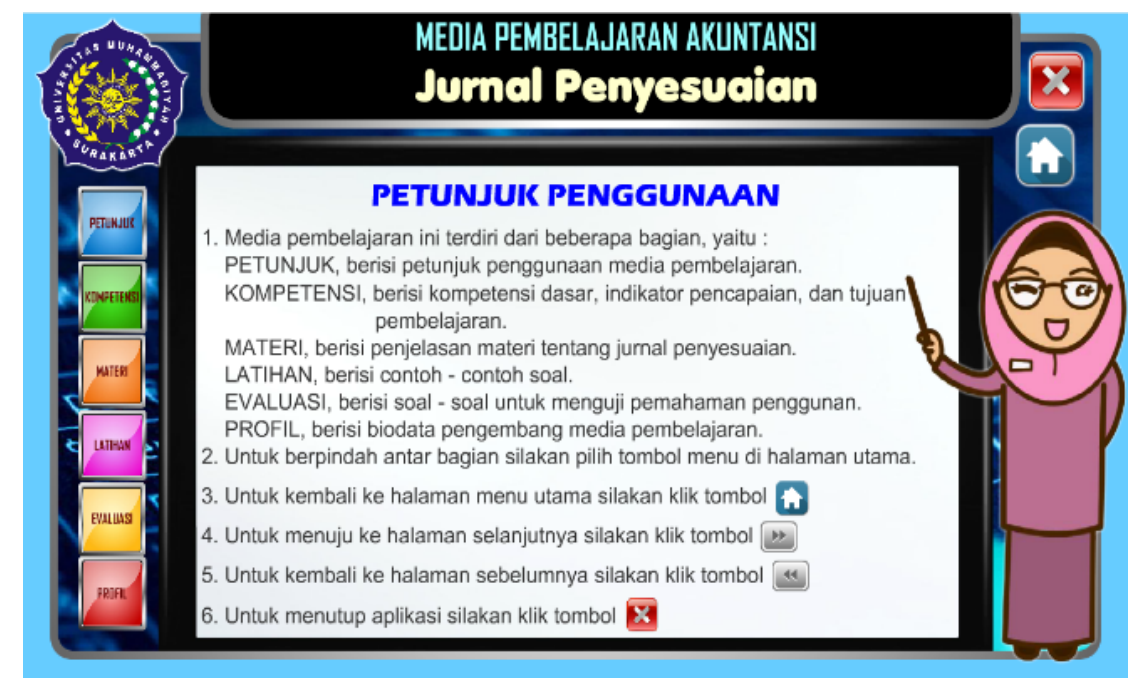

Fig. 1. Display of Adjustment Journal material of Adobe Flash CS6 Interactive Media based Instructional Media

In the Adobe Flash CS6 instructional media, there are exciting features that can help the learning process. These features consist of:

a. INSTRUCTIONS contains steps on how to use the instructional media.

b. COMPETENCY contains essential competencies, indicators of achievements, and learning goals.

c. MATERIAL contains an explanation of the materials on adjustment journals.

d. PRACTICE contains questions for practicing for evaluation preparation.

e. EVALUATION contains pre-test and post-test questions to measure the students' learning outcome.

PROFILE contains the data of the creator of the instructional media.

This research compares two classes, one which uses Adobe Flash based interactive media and another which uses the conventional teaching method. The accounting material studied is the adjustment journal. To find the difference, two classes were used which were the experiment class which used the Adobe Flash CS6 based instructional media that has been developed by the researcher, and the controlled class which used a lecture or conventional learning. The following is the result and analysis of the research of the experiment and controlled classes:

\subsection{Analysis of the difference of students' activeness in learning in using Adobe Flash Interactive media-based instructional media and conventional learning}

Students' activeness in the learning process can stimulate and develop their talent, they can also practice thinking critically, and problem-solving in the learning process.

In this research, data of students' activeness was obtained using the observation sheet with the following assessment indicators:

a. Active participation in carrying out their learning tasks 
b. Engaged in problem-solving

c. Ask questions to peers/teachers when they do not understand something

d. Try to find various information to solve a problem

e. Conduct group discussion

f. Assess their ability and the result they obtained

g. Train themselves in problem-solving [19].

Opportunities to use/ implement what they learned from completing their tasks/ problems

The result of students' activeness in the experiment and controlled classes based on the observation sheet can be seen in table 1 .

Table 1. Data of Students' Activeness in Learning Observation

\begin{tabular}{lcc}
\hline Variation Source & Experiment class & Controlled class \\
\hline $\mathrm{N}$ & 36 & 36 \\
Mean & 51.42 & 40.31 \\
Median & 52.50 & 41.00 \\
Mode & 53 & 41 \\
Std. Dev & 3.237 & 4.034 \\
Minimum & 39 & 34 \\
Maximum & 56 & 53 \\
\hline
\end{tabular}

From table 1, it can be seen that there is a difference in the result of the average score of students' learning activeness in the experiment class and controlled class. The average score for the experiment class is higher than the controlled class. Based on the Independent Sample t-Test, the tcount obtained was 12.889, and the ttable was 1.994 (tcount $>$ ttable). The significance level also showed 0.000 , which means that there is a significant difference between the score of learning activeness of the learning process using the Adobe Flash CS6 interactive media based instructional media and conventional learning.

By using the Adobe Flash CS6 interactive media based instructional media in learning accounting, the result of the observation showed that students were more enthusiastic in following the learning process that a dynamic learning atmosphere was created. Furthermore, students were seen to be more engaged in solving problems and participated more in completing their tasks. The instructional media gave the students more activities that involved their kinesthetic aspects. The visual display of the instructional media also made the students more motivated to observe and eager to ask questions due to their curiosity. On the other hand, in the conventional learning class which was dominated by the teacher's lecturing and students listening, the atmosphere of the class was mostly passive; the students felt bored and tended not to pay attention. These findings are similar to those found in Putri's [20] research that stated that flash media could increase students' activeness. Students are more active visually, orally, in listening, writing, drawing, metric activities, and mentally. 


\subsection{The difference of students' learning outcome in using Adobe Flash CS6 interactive media based instructional media compared to conventional learning}

Learning is an activity that involves both physic and mental. Thus the change that occurs must be reflected through students' physical and mental development. Students' learning achievement can be measured based on the magnitude of the range of change before and after students participate in a learning activity. According to Hamalik [21], the learning outcome is that when someone has learned there will be a change in their behaviour, for example, from not knowing to know, and from not understanding to understanding. From this research, in measuring the learning outcome, the researcher used a pre-test and post-test with questions related to the adjustment journal material. The learning outcome of the learning process using the Adobe Flash CS6 interactive media based instructional media can be seen in table 2 .

Table 2. Data of Students' Learning Outcome

\begin{tabular}{lcccc}
\hline Variation & \multicolumn{2}{c}{ Experiment Class } & \multicolumn{2}{c}{ Controlled class } \\
\cline { 2 - 5 } Source & Pre-test & Post-test & Pre-test & Post-test \\
\hline $\mathrm{N}$ & 36 & 36 & 36 & 36 \\
Mean & 52.64 & 89.72 & 52.08 & 71.25 \\
Median & 52.50 & 90.00 & 50.00 & 70.00 \\
Mode & 50 & 95 & $50^{\mathrm{a}}$ & 70 \\
Std. Dev & 4.998 & 6.088 & 4.837 & 4.837 \\
Minimum & 40 & 75 & 40 & 60 \\
Maximum & 65 & 100 & 65 & 85 \\
\hline
\end{tabular}

From table 2, it can be seen that there is a significant difference in the average deviation from the pre-test and post-test of the learning outcome at the beginning and the end of the experiment and controlled class. This is proven by the average of the pre-test in the experiment class using the Adobe Flash CS6 interactive media based instructional media was 52.64 and became 89.72 in the post-test whereas the average of the pre-test of the controlled class using conventional learning method was 52.08 and became 71.25 in the post-test. Based on the independent sample t-Test the tcount obtained was 14.254, and the ttable was 1.994 (tcount $>$ ttable). The significance level showed 0.000 which means that Ho is rejected, thus inferring that there is a significant difference in the learning outcome between students who used the Adobe Flash CS6 interactive media based instructional media and conventional learning. Aside from that, the calculation of the gain score found that the experiment class had a higher score compared to the controlled class with $0,78>0,39$. The gain score of the experiment class was within the high category while the controlled class was in the moderate category.

The research showed that by using the Adobe Flash CS6 interactive media based instructional media, the experiment class is better than the controlled class, which used conventional learning method. This is proven by the difference and the increase in the average of the learning outcome of the experiment class, which was higher than that of the controller class. The existence of the Adobe Flash CS6 interactive media based instructional media influences the difference in the learning outcome due to several factors. One of which is the delivery of the materials using a different concept. The learning process using the Adobe Flash CS6 interactive media based 
instructional media can interestingly display the materials. Hence, students can understand the materials better.

On the other hand, in the controller class, the conventional learning tends to be unable to make students understand the materials presented. This is due to the fact that conventional learning seems boring, and the concept of the delivery of the material is not attractive; thus, students tend not to pay attention to their teacher's explanation. This consequently results in the difference in the result of the learning outcome between the experiment class, which uses the Adobe Flash CS6 interactive media based instructional media and the controller class, which uses conventional learning method.

The finding of this research is in line with the study conducted by Priyadana and Suharmanto [22] which stated that there is an increase in the learning outcome after the implementation of Adobe Flash CS6 interactive media based instructional media. Where the improvement of the class that used Adobe Flash CS6 interactive media based instructional media increased by $25 \%$ whereas the controlled class, which used the conventional method only increased by $8 \%$. Although there was an increase in both classes in their post-test, the improvement in the learning outcome of the experiment class was more significant than the controlled class. The effectiveness of the implementation of the Adobe Flash CS6 interactive media based instructional media can increase creativity and broaden knowledge.

\section{Conclusion}

Based on the result of this research, it can be concluded that there is a difference in the students' activeness in learning in the learning process using the Adobe Flash CS6 interactive media based instructional media for the materials on adjustment journal in the subject of accounting in vocational school students compared to conventional learning. The increase in students' activeness lies in the average score of the experiment class, which was 51.42, while the controlled class was only 40.31. Aside from this, it was also proven that there is a difference in the learning outcome of students is learning using the Adobe Flash CS6 interactive media based instructional media and conventional learning. The increase in students' learning outcome lies in the average score of the experiment class at 89.72, while the controlled class was 71.25. The gain score of the experiment class was categorized as high, whereas the controlled class fell into the moderate category. The result of this research is expected to be able to increase teachers' motivation to be more innovative in using Adobe Flash CS6 interactive media based instructional media in their teaching-learning process so that they can increase the students' activeness and maximize their learning outcome.

\section{References}

[1] A. S. Macsuga-Gage, B. Simonsen, and D. E. Briere, "Effective Teaching Practices: Effective Teaching Practices that Promote a Positive Classroom Environment," Beyond Behav., vol. 22, no. 1, pp. 14-22, 2012.

[2] A. Kudryashova, T. Gorbatova, S. Rybushkina, and E. Ivanova, "Teacher's Roles to Facilitate Active Learning," Mediterr. J. Soc. Sci., vol. 7, no. 1, pp. 460-466, 2015.

[3] V.-E. Salca, R. Moldovan, and A. Vlaicu, "Interactive Tools for Learning Foreign Languages - Case Study: Cluj-Napoca German Cultural Centre,” vol. 54, no. 2, pp. 1- 
7, 2013.

[4] A. M. P. de Araujo and V. G. Slomski, "Active Learning Methods-An Analysis of Applications and Experiences in Brazilian Accounting Teaching," Creat. Educ., vol. 04, no. 12, pp. 20-27, 2013.

[5] M. Yamin, Kiat Pembelajaran Siswa. Jakarta: Ar-Ruzza Media, 2017.

[6] M. Silberman, Pembelajaran Aktif 101 Strategi untuk Mengajar secara Aktif. Jakarta Barat: PT Indeks, 2013.

[7] M. S. Medina, "Making students' thinking visible during active learning," Am. J. Pharm. Educ., vol. 81, no. 3, pp. 1-4, 2017.

[8] A. Paolini, "Enhancing teaching effectiveness and student learning outcomes.," J. Eff. Teach., vol. 15, no. 1, pp. 20-33, 2015.

[9] T. T. Lee and K. Osman, "Interactive multimedia module with pedagogical agents: Formative evaluation," Int. Educ. Stud., vol. 5, no. 6, pp. 50-64, 2012.

[10] F. T. Leow and M. Neo, "Interactive multimedia learning: Innovating classroom education in a Malaysian university," Turkish Online J. Educ. Technol., vol. 13, no. 2, pp. 99-110, 2014.

[11] G. Ogott and F. Odera, "Integration of Media and Technology in Teaching and Learning Kiswahili Language in Secondary Schools in Siaya County, Kenya," Int. J. Inf., vol. 2, no. 10, pp. 787-794, 2012.

[12] F. Aksit, H. Niemi, and A. Nevgi, "Why is active learning so difficult to implement: The Turkish case," Aust. J. Teach. Educ., vol. 41, no. 4, pp. 94-109, 2016.

[13] M. Tamrin, H. Azkiya, and S. G. Sari, "Problems Faced by the Teacher in Maximizing the Use of Learning Media in Padang," Al-Ta lim J., vol. 24, no. 1, p. 60, 2017.

[14] I. Made Rajendra and I. Made Sudana, "The Influence of Interactive Multimedia Technology to Enhance Achievement Students on Practice Skills in Mechanical Technology," J. Phys. Conf. Ser., vol. 953, no. 1, 2018.

[15] K. Kopecky, "Adobe Flash As Platform for Creation of Online Multimedia Educational Content," J. Technol. Inf., vol. 1, no. 3, pp. 118-121, 2009.

[16] H. Darmadi, Metode Penelitian Pendidikan Sosial. Bandung: Alfabet, 2014.

[17] Sutama, Metode Penelitian Pendidikan Kuantitatif, Kualitatif, PTK, $R \& D$. Surakarta: Fairuz Media, 2016.

[18] J. L. Badge, E. Dawson, A. J. Cann, and J. Scott, "Assessing the accessibility of online learning," Innov. Educ. Teach. Int., vol. 45, no. 2, pp. 103-113, 2008.

[19] N. Sudjana, sujana. Bandung: Sinar Baru Algensindo, 2010.

[20] D. . Putri, Siswandari, and B. Muchsini, "Peningkatan Keaktifan dan Prestasi Belajar Akuntansi Melalui Pendekatan Ctl dengan Media Flash di SMK," J. Tata Arta UNS, vol. 2, no. 1, pp. 162-172, 2016.

[21] D. Getz and T. Jamal, "Collaboration Theory and Commuity Tourism Planning," Ann. Tour. Res., vol. 22, no. 1, pp. 186-204, 1995.

[22] M. I. Priyadana, "Penerapan Media Berbasis Adobe Flash Professional Cs5 Untuk Meningkatkan ( Media Application Based on Adobe Flash Cs5 Professional To Increase Student Learning Outcomes in Learning Competence Straight Rack Gear )," J. Pendidik. Tek. Mesin, vol. 16, no. 2, pp. 96-100, 2015. 